El ecoturismo multidisciplinario como un enfoque para la conservación en África

\title{
Ecotourism as a multidisciplinary conservation approach in Africa
}

Hubert Cheung ${ }^{1 *}$

${ }^{1}$ World Green Organisation, $4^{\text {th }}$ Floor, 483 D-E Castle Peak Road, Lai Chi Kok, Hong Kong. Email: hubertcheung@thewgo.org, hcheung7@hotmail.com (HC).

${ }^{*}$ Corresponding author

\begin{abstract}
Introduction: Conservation biology addresses complex issues that require multidisciplinary solutions capable of addresing various ecological, social, cultural, economic, political and legal aspects. Compromises between biodiversity conservation and human development are inevitable given societal demands and funding constraints. Ecotourism has the potential to provide local stakeholders with socioeconomic benefits while achieving conservation objectives. Reported here is an expansion to a cost-benefit analysis of tourism in Kenya's national parks that explored issues and potential improvements to maximize benefits and minimize costs. Issues raised in this analysis are explored in the wider context of conservation in Africa. In particular, conservation in Africa would benefit from a greater involvement of local community stakeholders in ecotourism decision-making, the development of tourist interest in a wider range of wildlife, and a wider application of adaptive management principles.
\end{abstract}

Discussion and conclusions: Local communities as major conservation stakeholders. This section explores and emphasizes the importance of local communities as major stakeholders in conservation. In order for ecotourism to balance conservation and development objectives, local community stakeholders must be able to equitably share in socioeconomic benefits. Their engagement, involvement and empowerment is critical to the success of ecotourism as a multidisciplinary conservation approach.

Conservation prioritization and ecotourism diversification. This section discusses the need for ecotourism across the African continent to diversify beyond the traditional "Big Five". Expanding the viewing preferences and interests of different visitors can help draw attention and funding to less iconic species to achieve greater overall biodiversity conservation.

Monitoring and adaptive management. This section stresses the importance of scientific research and understanding to conservation objectives. Data need to be gathered systematically in ongoing monitoring and evaluation to facilitate adaptive management.

Key words: Adaptive management, Africa, conservation, cost-benefit analysis, ecotourism, local community, monitoring, stakeholder engagement, tourism diversification.

\section{Introduction}

As anthropogenic impacts on the natural world continue to mount, the importance of conservation efforts to protect biodiversity grows. Conservation is a field that transcends the traditional boundaries of pure sciences; it must produce solutions that address ecological concerns alongside human dimensions, including sociopolitical, economic, legal, cultural, aesthetic and spiritual considerations (McNeely 2006; Sanderson et al. 2008). The greatest challenge in conservation is translating a plan into action through implementation, which requires access to adequate resources (Hoeksta et al. 2002; Stephenson and Ntiamoa-Baidu 2010). Assessing the expected costs and benefits of conservation strategies can maximize ecological and socioeconomic returns and cost-effectiveness (Di Minin et al. 2013b). Prioritizing goals and actions can help make the most of limited resources in producing positive impacts for species and their habitats (Dietz 2010; Brown and Swaminathan 2010; Game et al. 2013). 
The realities of modern society coupled with resource constraints in conservation render trade-offs between biodiversity conservation and human development unavoidable (Di Minin et al. 2013b). Where applicable, accounting for potential economic benefits in decision-making can produce solutions that combine conservation and sustainable development objectives (Di Minin et al. 2013b). Conservation-based business, such as ecotourism, can provide socioeconomic benefits for local communities, representing a mutually beneficial approach to achieving conservation and economic development goals simultaneously (Di Minin et al. 2013b). Through the economic incentivizing of species conservation, ecotourism may hold a critical role in the ability of species to thrive in the natural world (Lindsey et al. 2007).

Ecotourism is defined as "responsible travel to natural areas that conserves the environment and improves the wellbeing of local people" by The International Ecotourism Society (TIES), representing a pragmatic compromise in balancing conservation objectives with human development in a sustainable manner (Sekercioğlu 2002; Eshun 2014; Frempong and Adjei 2014; TIES 2014). This form of tourism has the capacity to effect environmental, social, cultural and economic impacts at great scales; whether such potential is used for positive impacts or negative impacts depends on how it is carried out (Okech and Bob 2009). When applied in a fair and equitable manner, it offers conservationists an alternative approach to strict protectionism by allowing for the usually non-consumptive use of precious natural resources (Brooks 2012; Waylen and Mulder 2012). To maximize social and ecological benefits, ecotourism needs to be complemented with other suitable approaches and tools and may not be universally applicable due to constraints of geography, landscape, inadequate local ecological information, or sociocultural norms specific to each region or country (Coria and Calfucura 2012).

In Kenya, ecotourism contributes significantly to the economy and revolves around its 65 national parks and reserves (Ikiara and Okech 2002; Ramser 2007; Akama, Maingi and Camargo 2011). Through a process of monetary valuation, Cheung (2012) quantified the socioeconomic and environmental impacts of tourism in Kenya's national parks and found that the overall benefits outweigh the costs. Cheung (2012) estimated that the collective benefits range between Kenyan Shillings (KES) 47,328,086,850 and KES 67,052,853,000 annually, while evaluating all socioeconomic and environmental costs between KES 3,864,954,704 and KES 4,624,588,710 per year. This means that tourism in Kenya's protected areas brings a net benefit ranging from KES $21,531,098,140$ to KES 42,015,498,296 per annum once socioeconomic and environmental impacts are accounted for (Cheung 2012). Noting the assumptions and inherent difficulties in assigning monetary values to impacts, the author highlighted the overall trend that the socioeconomic and environmental benefits outweigh the costs as broadly representative of the impacts of tourism in Kenya's national parks (Cheung 2012). However, although the cost-benefit ratio is favorable to having tourism in Kenya's protected areas, there are stakeholders who benefit more than others, who in conttrast may directly and disproportionately bear more of the costs while receiving little benefit (Cheung 2012). The analysis by Cheung (2012) identified and discussed areas of the industry where improvements could further maximize benefits and minimize costs. The purpose of this paper is to expand on some of the issues discussed in Cheung's (2012) cost-benefit analysis, and place them into a wider context of taking an interdisciplinary approach to conservation on the African continent.

\section{Discussion}

\section{Local communities as major conservation stakeholders}

Conservation must take into account local contexts in planning and implementation, as local peoples and communities are inherently significant stakeholders (Hodgman 2005; Waylen et al. 
2010). Conservation efforts are most effective when all parties agree to common goals and how to achieve them; obstacles may emerge when these are unclear or poorly communicated (Hodgman 2005; Ahebwa 2012; van der Duim and Sandbrook 2012). Cheung (2012) echoed the sentiments of other researchers in noting that local communities were disempowered by an established neocolonial structure present in the ecotourism industry in Kenya that hinders local participation in decision-making (Scheyvens 1999; Coast 2002; Akama 2004; Manyara and Jones 2007). While it is the intention of governments and NGOs to improve the economic welfare of local and indigenous peoples, their paternalistic role in ecotourism development and management have effectively disengaged local stakeholders from the decision-making process (Coria and Calfucura 2012).

In spite of the favorable cost-benefit ratio, ecotourism has been unable to improve the livelihoods of local communities in Kenya. The description of benefits from revenue-sharing by local stakeholders as being "very minimal" reflects existing administrative inefficiencies and weaknesses in addition to the disempowerment of these communities (Beh and Lelengula 2009; Bruyere 2009; Cheung 2012). Given the widespread poverty that persists in the country, there is a need for ecotourism opportunities and revenue to be equitably and efficiently distributed (Sindiga 1995; Beh and Lelengula 2009; Bruyere 2009; Gusset et al. 2009; Hazzah2009; Mulder and Frank 2009). The employment of outside labor has also led to imbalances in local representation on tourism workforces (Manyara and Jones 2007; Beh and Lelengula 2009; Bruyere 2009). Okech and Bob (2009) found that involvement in tourism-related work was common among local communities adjacent to the Maasai Mara National Reserve and Amboseli National Park, and this included direct employment, receiving money from camping concessions, earning fees from manyatta (family settlement) visits, and from the sale of souvenir handicrafts. However, for local communities, these benefits were determined to be insufficient to offset the negative impacts of tourism in their local areas (Okech and Bob 2009). These problems are not unique to ecotourism in Kenya. Ecotourism has largely failed to deliver adequate socioeconomic benefits to local stakeholders in many other African nations (Bruyere 2009; Beh and Lelengula 2009; Coria and Calfucura 2012). Many researchers have stressed the importance of ensuring that local communities are able to share meaningfully in the socioeconomic benefits brought by ecotourism (Snyder and Sulle 2011; Ahebwa 2012; Tumusiime and Vedeld 2012; van der Duim and Sandbrook 2012; Shoo and Songorwa 2013; Yitbarek et al. 2013).

Conservation that is stakeholder-driven can both account for the needs of local peoples while helping to balance conservation and socioeconomic priorities and objectives (Klein et al. 2008). Community-based ecotourism is more likely to draw suitable compromises between conservation objectives, income generation, and community development (Kiss 2004). Local empowerment can be improved through a greater focus on local community leadership, independence and priorities, as well as by actively discouraging foreign elitism (Thompson and Homewood 2002; Manyara and Jones 2007). Increasing emphasis on partnerships between foreign tour operators and local communities can help unlock the industry's potential to aid economic development and reduce poverty in Kenya and across the continent (Manyara and Jones 2007). However, the decentralization of control over natural resources must be carefully conducted to prevent unfairness. For instance, Snyder and Sulle (2011) found in Tanzania that community members who are literate may take advantage of others who are not, and are thus unable to read contracts or revenue reports. Women and the elderly are other stakeholder groups that may become marginalized as decision-making powers are decentralized (Snyder and Sulle 2011).

Ecotourism can only act as a significant contributor to local livelihoods when benefits are shared in a mutually beneficial manner (Snyder and Sulle 2011). Ensuring that benefits are shared equitably has direct implications for conservation objectives, as many communities living in and around areas of high biodiversity simply have no economic incentives to conserve biodiversity otherwise (Okech and Bob 2009). Government and political commitment can be a critical factor in 
ensuring that opportunities and benefits are equitably shared. As a point of comparison, Maasai locals hold a large percentage of hotel and park positions in Kenya's Maasai Mara Game Reserve, whereas local communities have found it difficult to find employment related to ecotourism in Tanzania's Ngorongoro Conservation Area (Charnley 2005). In the latter case, capacity building in local communities through training and education can help local people improve their skills and employability. Many individuals do not have education beyond primary levels, even though they may possess in-depth knowledge of the local landscapes and natural history (Charnley 2005). The dependence of ecotourism on political stability, sufficient infrastructure, and tourism-associated development further highlights the need for increased community involvement in decisionmaking (Linsey et al. 2007). Longstanding issues involving corruption, bureaucratic bloat, and overarching government policies that conflict with conservation efforts have been discussed (Ferreira 2004; Parker and Khare 2005; Smith and Walpole 2005). Not only do such problems hinder economic development and exacerbate the cycle of poverty, they can also create hurdles for conservation efforts and hasten biodiversity loss (Smith and Walpole 2005). While this essay is unable to address these issues in further detail, they are fundamentally serious and require further investigation to ensure that conservation efforts, including ecotourism, can be effectively implemented without such hindrances.

Clearly, community-based ecotourism does not automatically guarantee conservation results or economic development for local stakeholders (Snyder and Sulle 2011; Coria and Calfucura 2012). However, the long-term cultural and social sustainability of ecotourism can be improved by empowering local communities, which can be achieved through direct participation, management, and ownership of conservation businesses (Akama 2011; Maingi and Camargo 2011; Di Minin et al. 2013b; Yitbarek et al. 2013). The development of cultural tourism experiences for tourists can help local communities conserve their cultural identity and can create opportunities for such stakeholders (Charnley 2005). For instance, the development of cultural boma settlement tours and walking safaris are able to provide local Maasai in Tanzania's Ngorongoro Conservation Area with opportunities for direct tourism involvement (Charnley 2005). These tourist experiences can operate with a relatively flexible schedule, allowing local community participants to maintain their traditional lifestyle as pastoralists and agriculturalists (Charnley 2005). These activities are also constructed on the unique skill set of local community members, where existing knowledge and familiarity with culture, local wildlife and landscape can be utilized to generate direct tourism income (Charnley 2005).

The growth of ecotourism can also help to address human-wildlife conflict, a significant challenge for the conservation of mammalian predators. Encounters between humans and predators are frequent in many parts of Africa, which inevitably leads to conflict. In multiple landuse areas, livestock depredation by carnivores causes economic losses for livestock owners and fuels retaliatory killings (Kolowski and Holekamp 2005; Kissui 2008; Hazzah 2009; Mulder and Frank 2009; Hemson et al. 2009). Despite hyenas being the most frequent raiders of livestock, lions are the most common targets in retaliatory killings because they are comparatively easier to track and kill, especially since they are more likely to defend carcasses against humans; other predators like cheetahs and hyenas are more likely to run away (Kissui 2008; Hazzah 2009; Mulder and Frank 2009). For local stakeholders, the economic incentive against conducting retaliatory killings and to protect other wildlife exists only when ecotourism revenues are large enough and if they are able to equitably share in these benefits (Romañach 2007; Lindsey and Woodroffe 2007; Bruyere 2009; Beh and Lelengula 2009; Hemson et al. 2009; Coria and Calfucura 2012). Equitably shared benefits from ecotourism can also provide pastoral and agricultural communities with an incentive to limit herd size, which can help prevent overgrazing and competition with wildlife (Snyder and Sulle 2011). Where other business interests may be present, such as commercial forestry and mining, socioeconomic considerations in conservation planning can help reduce 
potential policy conflicts (Di Minim et al. 2013). By accounting for both economic benefits and lost opportunity costs, conservation businesses like ecotourism can reduce conflicts between alternative development plans and facilitate conservation actions in a sustainable manner (Di Minin et al. 2013b).

Conservation prioritization and ecotourism diversification. Ecotourism is the fastest-growing sector in tourism, which happens to be the fastest growing industry in the world (Parker and Khare 2005; Lindsey et al. 2007; Coria and Calfucura 2012). It is able to generate funds for conservation while allowing wealth to be redistributed from developed to developing nations (Lindsey et al. 2007). However, its scope in Africa is limited by the viewing preferences of tourists, especially inexperienced safari-goers who are largely focused on the flagship "Big Five" of lions, elephants, buffaloes, leopards and rhinoceros (Lindsey et al. 2007; Di Minin et al. 2013a). Although responsible for attracting most foreign tourists to protected areas, these species are expensive to conserve. Lions, leopards and elephants can damage the livelihoods of their human neighbors while rhinos require costly anti-poaching strategies to be protected (Lindsey et al.2007; Di Minin et al. 2013a). The limited nature of funding renders the prioritization of conservation efforts- deciding how and where to protect what- imperative (Carwadine et al. 2008; Joseph, Maloney and Possingham 2009).

Funding is of the utmost importance in conservation as it largely dictates the feasibility and implementation of plans (Hoeksta et al. 2002; Stephenson and Ntiamoa-Baidu 2010). Conservation projects devoted to charismatic megafauna, often large, iconic mammal species, tend to receive more attention and funding than taxa that are not as well-known or appealing to the general public, such as native grasses or invertebrates (Bottrill et al. 2011; Buckeridge 2014). The viewing preferences of tourists in protected areas directly relate to the generation of conservation funds, as donor funding may be skewed towards areas or projects that contain these iconic species (Lindsey et al. 2007).

In South Africa, Di Minin et al. (2013a) echoed the findings of Lindsey et al. (2007) that visitors with lower income levels are willing to visit several protected areas to search for less observable, less iconic species, as opposed to wealthier tourists who are most interested in seeing charismatic megafauna without having to visit multiple protected areas to observe them. Similar trends can be observed in Kenya, where despite having 65 national parks and reserves, the majority of tourists choose to congregate in a few specific parks; the top five parks accounted for $54 \%$ of all visitor arrivals in 2009, while the top ten accounted for $80 \%$ (Republic of Kenya Ministry of Tourism and Wildlife 2010). Areas without the charismatic "Big Five" but where less iconic species are present should consider marketing specifically to domestic and African regional tourists as well as to those who may have more safari experience. This demographic tends to hold an interest in a greater diversity of wildlife and less easily observable species (Lindsey et al. 2007; Di Minin et al. 2013a). The development of less-visited parks may prevent or at least alleviate over-utilization of the most popular protected areas (Lindsey et al. 2007; Cheung 2012). Financial mechanisms, such as a "safari tax", can be considered for subsidizing the conservation of less iconic species, for developing consumer interest in a broader biodiversity base, and for raising general environmental awareness (Di Minin et al. 2013a). The development of public and tourist interest in a wider range of wildlife may ultimately increase and diversify donor funding to biodiversity conservation projects (Lindsey et al. 2007; Di Minin et al. 2013a).

Monitoring and adaptive management. Poor ecological and socioeconomic understanding of the situation, especially when exacerbated by inadequate stakeholder engagement, can create counterproductively negative attitudes among local communities towards conservationists (Jepson2001; Brickle and Chayadin 2001). There is no disagreement among conservation biologists that to be effective, conservation efforts must be built upon a foundation of strong scientific knowledge (Gordon2004; Hester and Festa-Bianchet 2004; Cardillo and Meijaard 2012). Cheung (2012) emphasized the need for relevant scientific data, such as population dynamics, habitat requirements, migration patterns, and behavioral responses to changing conditions, to be systematically recorded. This is necessary to facilitate the ongoing assessment of tourism impacts in Kenya's national parks. 
Ongoing monitoring of such information should be used to develop appropriate regulatory policies and to effectively mitigate impacts and prevent ecological damage (Cheung 2012).

Despite being widely promoted as important for improving conservation effectiveness, adaptive management, monitoring, and evaluation of conservation efforts have rarely been carried out (Kleimann et al. 2000; Regan et al. 2008; Swaisgood et al. 2011). Much of this comes down to the insufficiencies in funding for ongoing monitoring and review (Kleimann et al. 2000; Swaisgood et al. 2011). The impetus behind taking adaptive management approaches in conservation is clear. Plans and actions must evolve as knowledge and conditions change (Sanderson et al. 2008). Considerations for flexibility and feasibility when setting targets enable conservation efforts to cope with continually changing ecological conditions, social acceptance of conservation, and biological knowledge (Carwadine et al. 2008).

Cheung (2012) recommended that to ensure the long-term sustainability of tourism in Kenya's national parks, a system for systematically reviewing and evaluating tourism operations and programs is needed, starting with a structure for ongoing monitoring. The idea for a tourism-specific environmental impact assessment process was proposed to assess the appropriateness of tourism operations, evaluate impacts and ensure that local communities are able to participate equitably (Cheung 2012). It was further stipulated that such a process must take a multidisciplinary approach, in which moral, ethical, cultural and socioeconomic issues are addressed alongside ecological aspects. Ongoing monitoring is needed to inform such reviews and evaluations (Cheung 2012). Additionally, where the neo-colonial structure of the tourism industry persists, public participation mandated by an environmental impact assessment process should be able to draw some level of public participation (O'Faircheallaigh 2010). It is recommended that legislation and standards be established to implement a tourism-specific environmental impact assessment process.

While it is impossible for tourism to eliminate all negative impacts, the specific actions that are damaging can be reduced with proper training, certification, and regulatory enforcement (Akama2011; Maingi and Camargo 2011; Cheung 2012). For instance, many safari drivers do not avoid practices that excessively interfere with wildlife or damage the environment, such as driving too close to the animals, crowding around wildlife, and driving over delicate habitats (Cheung 2012). Standardized training and licensing by government authorities may help reduce the prevalence of such practices, especially when coupled with adequate enforcement. This could be by a government agency or by tour drivers themselves in the form of community policing (Ikiara and Okech 2002; Cheung 2012). The recent development of sustainability certification programs in the tourism industry has been driven by consumer behavior and increased awareness of sustainability in more affluent nations (Strambach and Surmeier 2013). Tourism certification schemes in Africa have traditionally focused on environmental issues in hospitality and accommodation. An example is Ecotourism Kenya's certification scheme for the country's tourist accommodations (Akama, Maingi and Camargo 2011). The incorporation of social and cultural dimensions in sustainability certification for ecotourism has been stressed, with some efforts now being made to develop appropriate indicators and standards (Akama 2011; Maingi and Camargo 2011; Stramback and Surmeier 2013). Measures to assess local community empowerment and participation in the industry should also be explored (Akama 2011; Maingi and Camargo 2011).

\section{Conclusions}

Conservation businesses, including ecotourism, have the potential to simultaneously protect endangered biodiversity while providing financial and social benefits to local stakeholders (Di Minin et al. 2013). To reiterate Cheung's (2012) findings, tourism in Kenya's protected areas brings an annual net benefit ranging from KES 21,531,098,140 to KES 42,015,498,296. Local stakeholders 
must be able to equitably share in these socioeconomic benefits for tourism to be able to achieve both conservation and development objectives. This can be done through the empowerment of local communities through direct participation in decision-making, management and ownership of conservation businesses (Akama 2011; Maingi and Camargo 2011; Di Minin et al. 2013b; Yitbarek et al. 2013).

Ecotourism holds significant value to conservationists, as it is an approach that can provide local stakeholders with an economic incentive to protect species for conservation (Lindsey et al. 2007). Diversifying current market interest in a greater variety of wildlife may increase donor funding for a wider range of conservation efforts (Lindsey et al. 2007; Di Minin et al. 2013a). Conducting ongoing monitoring enables conservation actions to evolve as knowledge and conditions change through a systematic process of reviews and evaluation (Sanderson et al. 2008; Cheung 2012). Capacity building to enhance local employment, adequate training, sustainability certification schemes, and regulatory enforcement can help reduce the negative impacts of tourism (Akama 2011; Maingi and Camargo 2011; Cheung 2012).

Understanding the costs and benefits of different conservation approaches can ensure that effective and efficient ecological and socioeconomic results are achieved with limited funds (Di Minin et al. 2013b). Conservation requires multidisciplinary solutions to tackle complex problems involving ecological, social, cultural, economic, political and legal aspects (McNeely 2006; Sanderson et al. 2008). Community-based ecotourism has the potential to establish a symbiotic relationship between tourism, local stakeholders and the natural world (Coria and Calfucura 2012). The potential of ecotourism in Africa to produce both positive ecological and socioeconomic results are inextricably linked and requires further development and improvement.

\section{Resumen}

Introducción: La biología de la conservación se ocupa de cuestiones complejas que requieren soluciones multidisciplinares capaces de enfrentarse a diversos aspectos ecológicos, sociales, culturales, económicos, políticos y jurídicos. Los compromisos entre la conservación de la biodiversidad y el desarrollo humano son las ineludibles demandas sociales y las limitaciones de financiación. El ecoturismo tiene el potencial de proporcionar a los interesados locales beneficios socioeconómicos, mientras se logran los objetivos de conservación. El presente escrito es una expansión al análisis de costo-beneficio del turismo en los parques nacionales de Kenia que explora cuestiones y las posibles mejoras para maximizar los beneficios y minimizar los costos. Las cuestiones planteadas en este análisis se exploran en el contexto más amplio de la conservación en África. En particular, la conservación en África, con el ecoturismo se beneficiaría de una mayor participación de las partes interesadas de la comunidad local toma de decisiones, el desarrollo de interés turístico en una gama más amplia de la vida silvestre, y una aplicación profunda en los principios de gestión adaptativa.

Discusión y conclusiones: Comunidades locales como principales grupos de interés de conservación. Esta sección explora y pone de relieve la importancia de las comunidades locales como principales interesados en la conservación. Para que en el ecoturismo se puedan equilibrar los objetivos de conservación y desarrollo, las partes interesadas de la comunidad local deben ser capaces de compartir equitativamente los beneficios socioeconómicos. Su compromiso, la participación y el empoderamiento es parte fundamental para el éxito del ecoturismo como un método de conservación multidisciplinario.

Conservación priorización y diversificación ecoturismo. En esta sección se discute la necesidad de ecoturismo en todo el continente africano para diversificar más allá del tradicional "Cinco Grandes". Ampliando las preferencias e intereses de los diferentes visitantes, esta visión puede ayudar a llamar la atención y financiación a las especies menos icónicas para lograr una mayor conservación de la biodiversidad en general.

Monitoreo y manejo adaptativo. En esta sección se hace hincapié en la importancia de la investigación científica y la comprensión de los objetivos de conservación. Los datos deben ser recogidos de forma sistemática en el seguimiento y la evaluación continua para facilitar la gestión adaptativa.

Palabras Clave: África, análisis, comunidad local, costo-beneficio de diversificación del turismo, conservación, ecoturismo, manejo adaptativo, seguimiento, grupos de interés. 


\section{Literarure cited}

Ahebwa, W. M., R.van der Duim, and C. Sandbrook. 2012. Tourism revenue sharing at Bwindi Impenetrable National Park, Uganda: a policy arrangements approach. Journal of Sustainable Tourism 20:377-394.

Акама, J. S. 2004. Neo-colonialism, dependency and external control of Africa's tourism industry. Taylor and Francis: London, UK.

Akama, J. S., S. Maingi, and B. A. Camargo. 2011. Wildlife conservation, safari tourism and the role of tourism certification in Kenya: a postcolonial critique. Tourism Recreation Research 36:281-291.

Bottrill, M. C., J. C. Walsh, J. E. M. Watson, L. N. Joseph, A. Ortega-Argueta, and H. P. Possingham. 2011. Does recovery planning improve the status of threatened species? Biological Conservation 144:1595-1601.

Brooks, J. S., K. A. Waylen, And M. B. Mulder. 2012. How national context, project design, and local community characteristics influence success in community-based conservation projects. Proceedings of the National Academy of Sciences of the United States of America 109:2126521270.

Bruyere, B. L., A. W. Beh, And G. Lelengula. 2009. Differences in perceptions of communication, tourism benefits, and management issues in a protected area of rural Kenya. Environmental Management 43:49-59.

BuckeridGe, J. 2014. Environmental ethics: an overview, assessing the place of bioscientists in society, supplemented with selected Australian perspectives. Integrative Zoology 9:14-23.

Cardillo, M., And E. MeijaArd. 2012. Are comparative studies of extinction risk useful for conservation? Trends in Ecology and Evolution 27:167-171.

Carwadine, J., C. J. Klein , K. A. Wilson, R. L. Pressey, and H. P. Possingham. 2009. Hitting the target and missing the point: target-based conservation planning in context. Conservation Letters 2:3-10.

Charnley, S. 2005. From nature tourism to ecotourism? The case of the Ngorongoro Conservation Area, Tanzania. Human Organization 64:75-88.

Cheung, H. 2012. Tourism in Kenya's national parks: a cost-benefit analysis. Studies by Undergraduate Researchers at Guelph 6:31-41.

COAST, E. 2002. Maasai socioeconomic conditions: a cross-border comparison. Human Ecology 30:79-105.

Coria, J., and E. Calfucura. 2012. Ecotourism and the development of indigenous communities: the good, the bad and the ugly. Ecological Economics 73:47-55.

Di Minin, E., I. Fraser, R. Slotow, and D. C. MacMillan. 2013. Understanding heterogeneous preference of tourists for big game species: implications for conservation and management. Animal Conservation 16:249-258.

Di Minin, E., D. C. Macmillan, P. S. Goodman, B. Escott, R. Slotow, and A. Mollanen. 2013. Conservation businesses and conservation planning in a biological diversity hotspot. Conservation Biology 27:808-820.

Dietz, L. A., M. Brown, and V. Swaminathan. 2010. Increasing the impact of conservation projects. American Journal of Primatology 72:425-440.

Eshun, G., F. Frempong, and P. O. W. Adjel. 2014. The prospects of ecotourism as a conservation and development tool in Bobiri Butterfly Sanctuary in Ghana. Research on Humanities and Social Sciences 4:40-47.

Ferreira, S. 2004. Problems associated with tourism development in Southern Africa: the case of transfrontier conservation areas. GeoJournal 60:301-310.

Game, E. T., P. Kareiva, and H. P. Possingham. 2013. Six common mistakes in conservation priority setting. Conservation Biology 27:480-485.

Gordon, I. J., A. J. Hester, and M. Festa-Bianchet. 2004. The management of wild large herbivores to meet economic, conservation and environmental objectives. Journal of Applied Ecology 41:1021-1031. 
Gusset, M., M. J. Swarner, L. Mponwane, K. Keletile, and J. W. McNutt. 2009. Human-wildlife conflict in northern Botswana: livestock predation by endangered African wild dog Lycaon pictus and other carnivores. Oryx 43:67-72.

Hazzah, L., M. B. Mulder, and L. Frank. 2009. Lions and warriors: social factors underlying declining African lion populations and the effect of incentive-based management in Kenya. Biological Conservation 142:2428-2437.

Hemson, G., S. Maclennan, G. Mills, P. Johnson, and D. Macdonald. 2009. Community, lions, livestock and money: a spatial and social analysis of attitudes to wildlife and the conservation value of tourism in a human-carnivore conflict in Botswana. Biological Conservation 142:2718-2725.

Hodgman, T. P. 2005. Incorporating partners in flight priorities into state agency operational plans: development of a management system for wetland passerines. US Forest Service General Technical Report PSW 191:213-218.

Hoekstra, J. M., J. A. Clark, W. F. Fagan, and P. D. Boersma. 2002. A comprehensive review of Endangered Species Act recovery plans. Ecological Applications 12:630-640.

IKIARA, M., AND C. ОKeCH. 2002. Impact of tourism on environment in Kenya: status and policy. KIPPRA Discussion Paper Number 19. Kenya Institute for Public Policy Research and Analysis - Productive Sector Division.

Jepson, P., N. Brickle, and Y. Chayadin. 2001. The conservation status of Tanimbar corella and blue-streaked lory on the Tanimbar Islands, Indonesia: results of a rapid contextual survey. Oryx 35:224-233.

Joseph, L. N., R. F. Maloney, and H. P. Possingham. 2009. Optimal allocation of resources among threatened species: a project prioritization protocol. Conservation Biology 23:328-338.

Kıss, A. 2004. Is community-based ecotourism a good use of biodiversity conservation funds? Trends in Ecology and Evolution 19:232-237.

Kıssul, B. M. 2008. Livestock predation by lions, leopards, spotted hyenas, and their vulnerability to retaliatory killing in the Maasai steppe, Tanzania. Animal Conservation 11:422-432.

Kleiman, D. G., R. P. Reading, B. J. Miller, T. W. Clark, M. Scott, J. Robinson, R. L. Wallace, R. J. Cabin, and F. Feleman. 2000. Improving the evaluation of conservation programs. Conservation Biology 14:356-365.

Klein, C. J., A. Chan, L. Kircher, A. J. Cundiff, N. Gardner, Y. Hrovat, A. Scholz, B. E. Kendall, and S. Airame. 2008. Striking a balance between biodiversity conservation and socioeconomic viability in the design of marine protected areas. Conservation Biology 22:691-700.

Kolowski, J. M., and K. E. Holekamp. 2005. Spatial, temporal, and physical characteristics of livestock depredations by large carnivores along a Kenyan reserve border. Biological Conservation 128:529-541.

Lindsey, P. A., R. Alexander, M. G. L. Mills, S. Romañach, and R. Woodroffe. 2007. Wildlife viewing preferences of visitors to protected areas in South Africa: implications for the role of ecotourism in conservation. Journal of Ecotourism 6:19-33.

Manyara, G., AND E. Jones. 2007. Community-based tourism enterprises development in Kenya: an exploration of their potential as avenues of poverty reduction. Journal of Sustainable Tourism 15:628-644.

McNeely, J. A. 2006. Systems or species? Approaches to conservation for the 21 st century. Integrative Zoology 1:86-95.

O'Faircheallaigh, C. 2010. Public participation and environmental impact assessment: purposes, implications and lessons for public policy making. Environmental Impact Assessment Review 30:19-27.

Окесн, R. N., AND U. Вов. 2009. Sustainable ecotourism management in Kenya. Ethiopian Journal of Environmental Studies and Management 2:57-65.

Parker, S., ANd A. Khare. 2005. Understanding success factors for ensuring sustainability in ecotourism development in Southern Africa. Journal of Ecotourism 4:32-46.

Ramser, T. 2007. Evaluating Ecotourism in Laikipia, Kenya: Assessing the Socio-economic Impact and Conservation Attitudes. MSc Thesis, University of Berne. Berne, Switzerland. 
Regan, H. M., L. A. Hierl, J. Franklin, D. H. Deutschman, H. L. Schmalbach, C. S. Winchell, and B. S. Johnson. 2008. Species prioritization for monitoring and management in regional multiple species conservation plans. Diversity and Distributions 14:462-471.

Republic of Kenya Ministry of Tourism and Wildlife. 2010. Hotel bed occupancy by zone. Accessed online on 18 Jan 2012 from < http://www.tourism.go.ke/ministry.nsf/doc/Hotel\%20Bed\%20 Occupancy\%20by\%20zone.xls/\$file/Hotel\%20Bed\%200ccupancy\%20by\%20zone.xls>.

Romañach, S. S., P. A. Lindsey, ANd R. Woodroffe. 2007. Determinants of attitudes towards predators in central Kenya and suggestions for increasing tolerance in livestock dominated landscapes. Oryx 41:185-195.

Sanderson, E. W., K. H. Redforda, B. Weber, K. Aune, D. Baldes, J. Berger, D. Carter, C. Curtin, J. Derr, S. Dorbott, E. Fearn, C. Fleener, S. Forrest, C. Gerlach, C. Gates, J. E.Gross, P. Gogan, S. Grassel, J. A. Hilty, M. Jensen, K. Kunkel, D. Lammers, R. List, K. Minkowski, T. Olson, C. Pague, P. B. Robertson, and B. Stephensom. 2008. The ecological future of the North American Bison: conceiving longterm, large-scale conservation of wildlife. Conservation Biology 22:252-266.

Scheyvens, R. 1999. Ecotourism and the empowerment of local communities. Tourism Management 20:245-249.

SekercioĞLu, C. H. 2002. Impacts of birdwatching on human and avian communities. Environmental Conservation 29:282-289.

Shoo, R. A., AND Songorwa, A. N. 2013. Contribution of eco-tourism to nature conservation and improvement of livelihoods around Amani nature reserve, Tanzania. Journal of Ecotourism 12:75-89.

SindigA, I. 1995. Wildlife-based tourism in Kenya: land use conflicts and government compensation policies over protected lands. Journal of Tourism Studies 6:45-55.

SMith, R. J., AND M. J. Walpole. 2005. Should conservationists pay more attention to corruption? Oryx 39:251-256.

Snyder, K. A., AND E. B. Sulle. 2011. Tourism in Maasai communities: a chance to improve livelihoods? Journal of Sustainable Tourism 19:935-951.

Stephenson, P. J., And Y. Ntiamoa-Baidu. 2010. Conservation planning for a widespread, threatened species: WWF and the African elephant Loxodonta africana. Oryx 44:194-204.

Strambach, S., And A. Surmeier. 2013. Knowledge dynamics in setting sustainable standards in tourism the case of 'Fair Trade in Tourism South Africa'. Current Issues in Tourism 16:736-752.

Swaisgood, R. R., F. W. Wei, W. J. McShea, D. E. Wildt, A. J. Kouba, And Z. J.Zhang. 2011. Can science save the giant panda (Ailuropoda melanoleuca)? Unifying science and policy in an adaptive management paradigm. Integrative Zoology 6:290-296.

The International Ecotourism Society. 2014. What is Ecotourism? Accessed online on 10 Dec 2014 from < http://www.ecotourism.org/what-is-ecotourism>.

Thompson, M., AND K. Homewood. 2002. Entrepreneurs, elites, and exclusion in Maasailand: trends in wildlife conservation and pastoralist development. Human Ecology 30:107-138.

Tumusime, D. M., and P. Vedeld. 2012. False promise or false premise? Using tourism revenue sharing to promote conservation and poverty reduction in Uganda. Conservation and Society 10:15-28.

Waylen, K. A., A. Fischer, P. J. K. McGowan, S. J. Thirgood, and E. J. Milner-Gulland. 2010. Effect of local cultural context on the success of community-based conservation interventions. Conservation Biology 24:1119-1129.

Yitbarek, T. W., D. Tadie, G. Timer, And A. Fischer. 2013. Evaluating governance processes in the sharing of revenues from wildlife tourism and hunting in Ethiopia. Environmental Conservation 40:253-265. 
Summited: October 17, 2014

Review: December 10, 2014

Accepted: December 17, 2014

Associated editor: William Lidicker 
42 THERYA Vol.6(1):31-41 